\title{
MENINGKATKAN KEMAMPUAN BERPIKIR KRITIS MELALUI MODEL PEMBELAJARAN PAIKEM TIPE DIRECT INSTRUCTION
}

\author{
Eva Nuryanti ${ }^{1}$, Tati Heryati², llah ${ }^{3}$ \\ 1,2,3 Program Studi Pendidikan Akuntansi, Universitas Galuh JL.R.E Martadinata no. 150, Ciamis, Indonesia \\ Email: evanuryanti@gmail.com, tati.cipari@gmail.com
}

\begin{abstract}
This research is motivated by the low critical thinking ability of students which causes students to be less active in the learning process and also in the use of inappropriate learning models. Responding to these problems, the authors apply learning models in the experimental class and conventional learning methods in the control class. The purpose of this study was to obtain an overview of improving students' critical thinking skills using the PAIKEM Direct Instruction type learning model at the initial and final measurements, and to compare the improvement of students' critical thinking skills using conventional learning models in Economics subjects in Basic Competencies of Business Entity Concepts. In the Indonesian Economy. The research method used is the experimental method (Quasi Experimental) with the Nonequivalent Control Group Design. The results of data analysis in this study showed that there was an increase in students' critical thinking skills in the experimental class. This research can be concluded that learning that uses the PAIKEM learning model Direct Instruction type has an effect on increasing students' critical thinking skills.
\end{abstract}

Keywords: Direct Instruction, critical thinking skills

\begin{abstract}
ABSTRAK
Rendahnya kemampuan berpikir kritis peserta didik merupakan permasalahan yang dihadapi dunia pendidikan (sekolah) karena faktor ini merupakan salah satu hal yang mengakibatkan rendahnya hasil belajar,atas dasar itulah yang melatar belakangi penelitian ini , salah satu upaya untuk meningkatkan kemampuan berpikir kritis dalam rangka meningkatkan hasil belajar yaitu dengan memilih model pembelajaran dengan tipe pembelajaran yang tepat. Tujuan dari penelitian ini untuk mengetahui 1) peningkatan hasil belajar dengan menerapkan model pembelajaran PAIKEM tipe Direct 2) peningkatan hasil belajar dengan menerapkan metode konvensional 3) peningkatan hasil belajar yang menerapkan model PAIKEM tipe Direct Intruction dengan metode konvensional. Penelitian ini menggunakan metode eksperimen (quasi eksperimental ) dengan desain nonequivalentt qontrol group desain dengan analisis data uji t. Penelitian ini menyimpulkan hasil belajar yang menerapkan model pembelaajran PAIKEM Tipe Direct Instruction lebih tinggi dibanding dengan metode konvensioanl.
\end{abstract}

Kata kunci: Direct Instruction, Kemampuan Berpikir Kritik

Cara sitasi: Nuryanti, E., Heryati, T., \& Ilah. (2021). Meningkatkan Kemampuan Berfikit Kritis Melalui Model Pembelajaran PAIKEM Tipe Direct Instruction. J-KIP (Jurnal Keguruan dan IImu Pendidikan), 2 (3), 153-160. 


\section{PENDAHULUAN}

Pendidikan dilihat dari sudut pandang tertentu akan berbeda pengertiannya akan tetapi maksudnya tertuju pada peningkatan kualitas sumber daya manusia. Didalam Undang-Undang Sistem Pendidikan Nasional No.20 Tahun 2003, menyebutkan bahwa pendidikan adalah usaha sadar dan berencana untuk mewujudkan suasana belajar dan proses pembelajaran agar peserta didik secara aktif mengembangkan potensi dirinya untuk memiliki kekuatan spiritual keagamaan, pengendalian diri, kepribadian, kecerdasan, akhlak mulia, serta keterampilan yang diperlukan dirinya, masyarakat, bangsa dan Negara, tujuan dari pembelajaran yaitu tercapainya perubahan perilaku peserta didik untuk menjadi lebih baik sebagai bentuk perolehan hasil belajar salah satunya dengan meningkatkan kemampuan berpikir kritis peserta didik. Berpikir kritis adalah mengkelompokan, mengorganisasikan, mengingat, dan menganalisis informasi yang diperlukan, menguji, menghubungkan dan mengevaluasi semua aspek dari situasi masalah. Penjelasan tersebut menegaskan bahwa berpikir kritis ialah kemampuan siswa untuk menganalisis ide-ide atau gagasan lalu memilih serta mengidentifikasi dalam menghasilkan suatu keputusan dengan kata lain kemampuan berpikir kritis akan melatih seseorang dalam memahami serta menganalisis suatu masalah sampai dengan memecahkan masalah tersebut dalam menggali informasi dari berbagai sumber. Berpikir kritis sangat penting dalam pembelajaran, karena merupakan tujuan ideal yang berkaitan dengan pendidikan modern.

Dalam upaya meningkatan kemampuan berpikir kritis yang merupakan salah satu komponen hasil belajardihadapkan pada beberapa masalah, salah satu upaya untuk mengatasi masalah tersebut sekolah sudah menentukan nilai KKM, namun upaya tersebut belum bisa mencapai tujuan yang diharapkan yaitu masih adanya kegiata remedial dalam proses pembelajran. Selain KKM upaya yang bisa dilakukan untuk mengatasi masalah tersebut yaitu dengan adanya kegiatan yang dilakukan oleh pendidik dengan memilih model pembelajaran yang tepat. Untuk meningkatan kemampuan berpikir kritis peserta didik model pembelajaran PAIKEM tipe direct instruction ini menuntut peserta didik untuk mempunyai pengetahuan deklaratif dan pengetahuan prosedural.

Hanya sedikit sekolah yang benar-benar mengajarkan siswanya untuk mengembangkan kemampuan berpikir kritis, biasanya sekolah menghabiskan waktu untuk mengajar siswa dengan memberikan satu jawaban yang benar, sehingga kegiatan pembelajaran di kelas kurang mendorong siswa untuk memperluas pemikiran mereka dengan menciptakan ide-ide baru yang sesuai dengan kemampuan siswa. Keterampilan berpikir kritis merupakan pemikiran yang bersifat selalu ingin tahu terhadap informasi yang ada untuk mencapai suatu pemahaman yang mendalam (Yustyan, dkk dalam Afifah, IImiati, \& Toto (2020)

Menurut Aryansyah (2021) salah satu upaya yang dapat dilakukan oleh seorang pendidik dalam menggaktifkan siswa pada saat proses pembelajaran adalah memberikan kesempatan kepada siswa untuk mengajukan pertanyaan dan menjawab pertanyaan dari pendidik maupun temannya yang mana pertanyaan tersebut berkaitan dengan materi yang sudah diajakan.

Madrasah Aaliah Daarussalaam Karangnunggal salah satu sekolah yang dalam proses pembelajaran pada umumnya masih didominasi oleh pendidik sehingga kurang memberi kesempatan bagi peserta didik untuk berkembang secara mandiri, hal ini mengakibatkan penumpukan informasi bagi peserta didik dan lambatnya proses berpikir kritis. Pendidik selalu menuntut peserta didik untuk belajar, tetapi tidak mengajarkan bagaimana peserta didik seharusnya belajar dan menyelesaikan masalah. Hal ini dapat dilihat pada tabel di bawah terdapat hasil ulangan harian peserta didik.

Kemampuan berpikir kritis peserta didik di MA Daarussalaam Karangnunggal dapat dilihat dari rata-rata ulangan harian kelas $\mathrm{X}$ pada mata pelajaran Ekonomi. 
Tabel 1. Nilai Mata Pelajaran Ekonomi Kelas X MA Darussalam Karangnunggal

\begin{tabular}{|c|c|c|c|c|c|c|c|c|c|c|}
\hline \multirow{2}{*}{ No } & \multirow{2}{*}{ Kelas } & \multirow{2}{*}{$\begin{array}{l}\text { Jumlah } \\
\text { Siswa }\end{array}$} & \multirow{2}{*}{ KKM } & \multicolumn{3}{|c|}{ Nilai } & \multicolumn{4}{|c|}{ Jumlah Ketuntasan Siswa } \\
\hline & & & & Tinggi & Rendah & Nilai Rata-rata & Tuntas & $\%$ & Tidak Tuntas & $\%$ \\
\hline 1 & XIPS 1 & 24 & 70 & 75 & 40 & 63,43 & 14 & 58 & 10 & 42 \\
\hline 2 & XIPS 2 & 21 & 70 & 78 & 35 & 63 & 11 & 52 & 10 & 48 \\
\hline & $\Sigma$ & 45 & & & & & 25 & 56 & 20 & 44 \\
\hline
\end{tabular}

Sumber : MA Darussalam Karangnunggal

Berdasarkan tabel di atas Kriteria Ketentuan Minimal (KKM) untuk mata pelajaran Ekonomi kelas $\mathrm{X}$ yaitu 70 .Sebagian peserta didik sudah ada yang mencapai nilai diatas 70 , tetapi masih ada peserta didik yang mendapatkan nilai dibawah 70 . Data diatas juga menunjukan bahwa terdapat kesenjangan yang sangat jauh antara nilai tertinggi dengan niali terrendah kelas X IPS 1 yaitu 75 dan 40; sedangkan di kelas X IPS 2 kesenjangan antara nilai tertinggi dengan nilai terrendah yaitu 78 dan 35 .

Untuk meningkatkan kemampuan berpikir kritis peserta didik penulis berasumsi bahwa model pembelajaran yang dapat memacu semangat setiap peserta didik untuk secara aktif terlibat dalam pengalaman belajarnya dan yang relevan dengan mata pelajaran ekonomi. Salah satu upaya untuk mengatasi masalah yang ada dan akan meningkatkan kemampuan berpikir kritis peserta didik yaitu dengan menggunakan model pembelajaran PAIKEM Tipe pembelajaran langsung (Direct Instruction).

Model instruksi langsung adalah suatu model pengajaran yang terdiri dari penjelasan guru mengenai konsep atau keterampilan baru, melibatkan guru bekerja dengan siswa secara individual, atau dalam kelompok-kelompok kecil (Watanabe et al., 2013) berfokus pada mencapai target pembelajaran dengan memberikan pelatihan keterampilan yang erat kaitannya dengan target. Pembelajaran Langsung (Direct Instruction) disebut juga sebagai suatu model pembelajaran yang bersifat berpusat pada guru.Dalam menerapkan pembelajaran langsung guru harus mendemonstrasikan pengetahuan atau keterampilan yang dilatihkan kepada sisiwa secara selangkah demi selangkah.

Berdasarkan uraian di atas penulis berasumsi bahwa model pembelajaran PAIKEM Tipe Direct Instruction merupakan metode pembelajaran yang tepat untuk diterapkan dalam mata pelajaran ekonomi, supaya dapat meningkatkan kemampuan berpikir kritis peserta didik. Penulis tertarik untuk mengadakan penelitian dengan judul "Pengeruh Model Pembelajaran PAIKEM TipeDirect InstructionTerhadap Peningkatkan Kemampuan Perpikir Kritis Peserta Didik Pada Mata Pelajaran Ekonomi Di Ma Darussalam Karangnunggal"

Terdapat penelitian terdahulu yang relevan ada persamaan dan perbedaan antara penelitian diantaranya: 1) Ilham Sidik dan Hendri Winata. (2016) Meningkatkan hasil belajar siswa melalui penerapan model pembelajaran direct instruction.Persamaan terdapat pada variable $(X)$ Pembelajaran direct instruction.Perbedaannya yaitu pada variable (Y) Meningkatkan hasil belajar. 2) Rameyanti Tampubolan. (2018) Pengaruh Model Pembelajaran PAIKEM Terhadap Hasil Dan Motivasi Belajar Siswa.Persamaan terdapat pada variable $(X)$ Model Pembelajaran PAIKEM.Perbedaannya yaitu pada variable (Y) Hasil dan Motivasi Belajar. 3) Dyah Kurniastuti. (2018) Peningkatan Kemampuan Berpikir Kritis Dan Prestasi Belajar Sisiwa Melalui Penggunaan Model Pembelajaran Problem Solving Dilengkapi Dengan Smart Card Pada Materi Kelautan Dan Hasil Kali Kelautan.Persamaan terdapat pada variable (Y) Peningkatan kemampuan berpikir kritis.Perbedaan terdapat pada variable $(X)$ model pembelajaran problem solving.4) Khilda Nurul. (2019) Pengaruh Model Pembelajran Problem Based Learning Untuk Meningkatkan Kemampuan Berpikir Kritis Peserta Didik Pada Pelajaran IPS Kelas VIII di SMP N 1 Tasikmalaya.Persamaan terdapat variable $(Y)$ Pengaruh Model Pembelajaran PAIKEM.Perbedannya yaitu pada variable (X) Kemampuan Berpikir Statistik Siswa. 3) Nirwan. Dkk. (2019) Penggunaan Model Pembelajaran Direct Instruction Berbasis Etnosains Dalam Pembelajaran Fisika Untuk Meningkatkan Kemampuan Berpikir Kritis Siswa.Persamaan pada variable (X) 
Pembelajaran direct instruction dan variable (Y) Meningkatkan kemampuan berpikir kritis.Perbedaanya yaitu menggunakan metode Berbasis Etnosains Dalam Pembelajaran Fisika.

Setiap penelitian yang dilakukan tentunya mempunyai maksud dan manfaat yang ingin dicapai oleh penulis, berdasarkan permasalahan diatas tujuan penelitian ini untuk mengetahui:

1) Peningkatan kemampuan berpikir kritis peserta didik pada kelas yang menggunakan model pembelajaran PAIKEM Tipe Direct Instruction pada pengukuran awal (pretest) dan pengukuran akhir (posttest) di kelas eksperimen. 2) Peningkatan kemampuan berpikir kritis peserta didik pada kelas yang menggunakan metode pembelajaran konvensional pada pengukuran awal (pretest) dan pengukuran akhir (posttest) di kelas Kontrol. 3) Perbedaan peningkatan kemampuan berpikir kritis peserta didik yang menggunakan model pembelajaran PAIKEM Tipe Direct Instruction dengan yang menggunakan metode pembelajaran konvensional pada pengukuran akhir (posttest).

Kegunaan Teoritis dari penelitian ini adalah :Hasil penelitian ini diharapkan dapat memberikan kontribusi terhadap perkembangan ilmu pendidikan terutama yang berkaitan dengan penggunaan model pembelajaran PAIKEM Tipe Direct Instruction terhadap berpikir kritis peserta didik dalam proses pembelajaran. Sedangkan Kegunaan Praktis dari penelitian ini adalah: 1) Bagi Sekolah, Memberikan masukan kepada pihak sekolah untuk penerapan model pembelajran yang tepat dalam proses pembelajran untuk meningkatkan kemampuan berpikir kritis peserta didik. 2) Bagi guru, Sebagai masukan dalam mengelola dan meningkatkan strategi belajar-mengajar serta mutu pengajaran, sebagai bahan informasi dalam memencing peserta didik untuk berpikir kritis yaitu dengan mengunakan model PAIKEM Tipe Direct Instruction. 3) Bagi Siswa, Agar peserta didik meningkatkan pemehamannya mengenai materi yang telah disampaikan dan memancing peserta didik untuk menggali pengetahuan dan kemampuan berpikir kritis dalam proses pembelajran. 4) Bagi Peneliti, Hasil penelitian ini dapat menambah wawasan serta pengetahuan dalam bidang pendidikan dan mengetahui pentingnya dalam menggunakan model dan metode yang tepat dalam pembelajaran bagi peserta didik serta memberikan pengalaman secara teknis untuk menerapkan teori yang selama diajarkan dibangku kuliah dengan membandingkannya secara praktek di lapangan.

\section{METODE PENELITIAN}

Dalam penelitian ini metode yang digunakan adalah penelitian eksperimen.Metode penelitian eksperimen ini akan digunakan untuk menyelidiki dan memprediksi ada tidaknya pengaruh penerapan model pembelajaran problem based learning terhadap hasil belajar peserta didik kelas $X$ pada mata pelajaran Ekonomi di MA Daarussalaam Karangnunggal. Desain yang akan digunakan dalam penelitian ini adalah "Nonequivalent Control Group Design".

Tabel 2. Desain penelitian Quasi Experimental Design dengan tipe Non-equivalent Control Group Design

\begin{tabular}{|c|c|c|c|c|}
\hline & Kelas & Test Awal & Perlakuan & Test Akhir \\
\hline$(\mathrm{R})$ & Eksperimen & 01 & $\bar{X}$ & $\mathrm{O} 2$ \\
\hline (R) & Kontrol & 03 & - & 04 \\
\hline
\end{tabular}

Keterangan :

$O_{1} \quad$ Tes awal kelas eksperimen untuk mengetahui pengetahuan awal siswa

$\mathrm{O}_{3}$ Tes awal kelas kontrol untuk mengetahui pengetahuan awal siswa

X Perlakuan diberikan kepada kelas eksperimen,yaitumodel Kooperatif tipescramble.

$\mathrm{O}_{2}$ Tes akhir kelas eksperimen setelahmengikutipembelajaran denganmelakukan penerapan model kooperatif tipe scramble

$\mathrm{O}_{4}$ Tes akhir kelas kontrol setelah mengikuti pembelajaran menggunakan modelPembelajarankonvensional. 
Variabel independen $(X)$ dalam penelitian ini adalah model PAIKEM Tipe Direct Instruction, sedangkan variable dependen $(Y)$ dalam penelitian ini adalah kemampuan berpikir kritis peserta didik.

Populasi dalam penelitian ini adalah peserta didik kelas X IPS Mata Pelajaran Ekonomi MA Daarussalaam Karangnunggal yang berjumlah 2 kelas dengan jumlah peserta didik 45 orang. Teknik pengambilan sampel menggunakan teknik Sampling Jenuh menurut (Sugiyono, 2016) yaitu teknik penentuan sampel bila semua anggota populasi digunakan sebagai sampel.Untuk pengambilan sampel ditentukan oleh nilai Pretest yang kemudian diuji homogenitas dan digunakan 2 kelas berdasarkan hasil uji homogenitas.

Teknik pengumpulan data yang digunakan dalam penelitian ini adalah sebagai berikut:

1) Studi Dokumentasi

Studi dokumentasi yang dilakukan dalam penelitian ini adalah mengumpulkan nilai ulangan harian peserta didik kelas X IPS di MA Daarussalaam Karangnunggal.

2) Observasi

Kegiatan observasi dalam penelitian ini dengan melakukan pengamatan selama proses pembelajaran berlangsung.

3) Test

Tes yang dilakukan berupa pretest dan posttest.Tes awal (Pretest) dilakukan pada awal penelitian dengan tujuan untuk mengetahui serta mengukur pengetahuan peserta didik sebelum dilaksanakan pembelajaran. Tes akhir (Posttest) dilakukan pada akhir penelitian dengan tujuan untuk mengetahui dan mengukur hasil belajar peserta didik setelah dilakukan penerapan model pembelajaran PAIKEM Tipe Direct Instruction.

\section{HASIL PENELITIAN DAN PEMBAHASAN}

Tabel 3. Rekapitulasi Hasil Penelitian

\begin{tabular}{|c|c|c|c|c|c|}
\hline Kelas & $\begin{array}{l}\text { Kemampuan } \\
\text { berpikir kritis }\end{array}$ & thitung & ttabel & Simpulan & Uji Hipotesis \\
\hline $\begin{array}{l}\text { Eksperimen } \\
(\mathrm{X} 1)\end{array}$ & 87,5 & \multirow{2}{*}{$\begin{array}{l}\text { 1. } 6,30 \\
\text { 2. } 6,02 \\
\text { 3. } 1,58\end{array}$} & \multirow{2}{*}{$\begin{array}{l}1,67 \\
1,68\end{array}$} & \multirow{2}{*}{$\begin{array}{c}\text { Ha diterima } \\
\text { Ho ditolak }\end{array}$} & \multirow{2}{*}{$\begin{array}{l}\text { Terdapat perbedaan kemampuan berpikir } \\
\text { kritis peserta didik yang menggunakan } \\
\text { Metode Pembelajaran PAIKEM Tipe } \\
\text { Direct Instructiondenganyang } \\
\text { menggunakan Metode Pembelajaran } \\
\text { Konvensional. }\end{array}$} \\
\hline $\begin{array}{c}\text { Kontrol } \\
(\mathrm{X} 2)\end{array}$ & 72,38 & & & & \\
\hline
\end{tabular}

Sumber: Perhitungan peneliti tahun 2021

Berdasarkan data rekapitulasi hasil perhitungan uji hipotesis yang dimasukan kedalam grafik sebagai berikut:

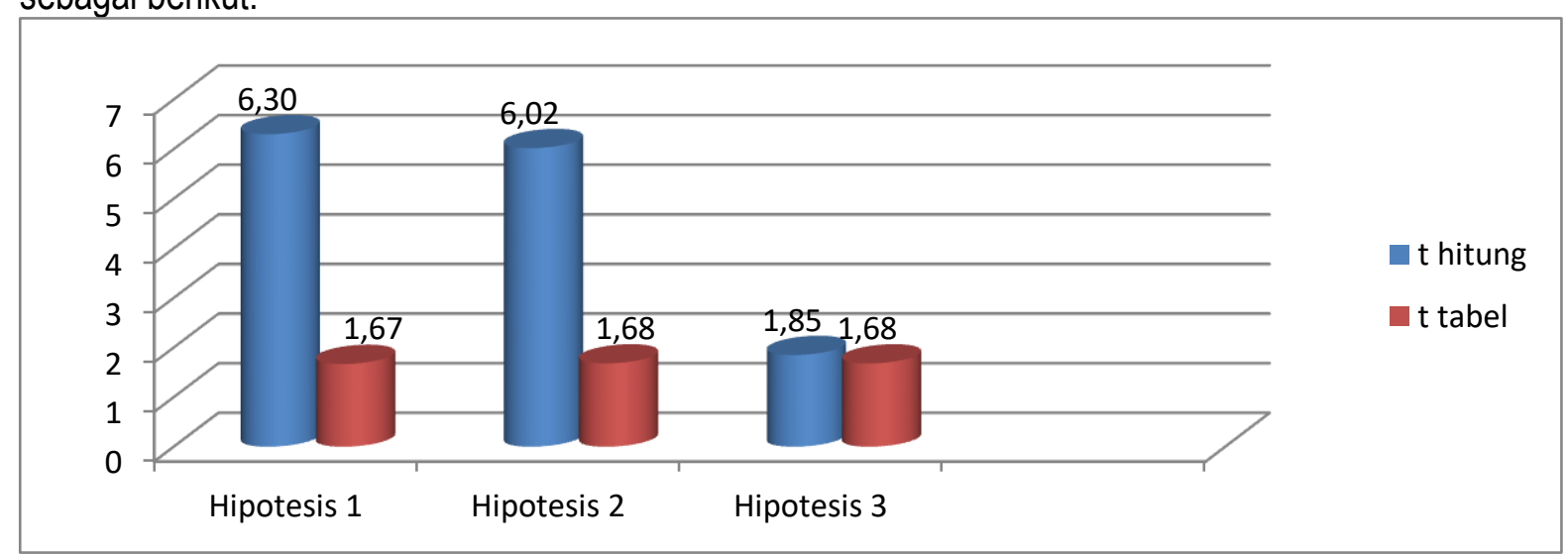


Pada hipotesis 1 terdapat Perbedaan kemampuan berpikir kritis peserta didik yang menggunakan model pembelajaran PAIKEM Tipe Direct Instruction pada pengukuran awal (pretest) dan pengukuran akhir (posttest) terdapat peningkatan kemampuan berpikir kritis peserta didik yang signifikan yaitu dengan selisih nilai sebesar 41,25 apabila dipersentasekan sebesar $94 \%$, besarnya persentase ini membuktikan bahwa penerapan model pembelajaran PAIKEM Tipe Direct Instruction sangat tepat digunakan pada Mata Pelajaran Ekonomi Kompetensi Dasar Konsep Badan Usaha dalam Perekonomian Indonesia. Pada hipotesis 2 terdapat peningkatan nilai dengan selisih yaitu sebesar 28,57 atau apabila diperesentasekan sebesar $65,08 \%$. Hal ini menggambarkan peningkatan kemampuan berpikir kritis peserta didik tersebut membuktikan bahwa metode pembelajaran konvensional tepat digunakan pada Mata Pelajaran Ekonomi Kompetensi Dasar Konsep Badan Usaha dalam Perekonomian Indonesia. Sedangkan pada hipotesis 3 Model Pembelajaran PAIKEM Tipe Direct Instruction lebih tinggi dibandingkan kemampuan berpikir kritis peserta didik yang menggunakan metode pembelajaran konvensional, hal ini dapat dilihat dari persentase pengukuran akhir sebesar $94 \%$ sedangkan Metode Pembelajaran Konvensional sebasar 65,08\% terdapat peningkatan nilai dengan selisih sebasar $28,92 \%$.Sebaiknya guru ekonomi dalam kompetensi dasar konsep badan usaha dalam perekonomian Indonesia ini menerapkan Model Pembelajaran PAIKEM Tipe Direct Instructionkarena terbukti dapat meningkatkan kemampuan berpikir kritis peserta didik apabila dibandingkan dengan Metode Pembelajaran Konvensional. Hal ini sesuai dengan keunggulan Model Pembelajaran PAIKEM Tipe Direct Instruction diantaranya yaitu proses pembelajaran yang lebih berorientasi pada peserta didik, sehingga peserta didik memiliki kebebasan pendapatkemudian peserta didik menjadi lebih kreatif dalam merangkai kata dengan bahasa sendiri dan melatih konsentrasi siswa untuk fokus pada peta konsep yang disajikan guru. Hal ini sejalan dengan teori belajar Konstruktivistik yang dikemukakan oleh Piaget yang menyatakan bahwa "pengetahuan tumbuh dan berkembang melalui pengalaman. Pemahaman berkembang semakin dalam dan kuat apabila selalu diuji oleh berbagai macam pengalaman baru. Bagi Piaget pengetahuan adalah konstruksi (bentukan) dari kegiatan atau tindakan seseorang."

Berdasarkan teori konstruktivistik diketahui bahwa pengetahuan peserta didik tidak diperoleh secara pasif melainkan ditemukan sendiri oleh peserta didik dengan cara berinteraksi langsung dengan lingkungan. Melalui interaksi langsung dengan lingkungan peserta didik dapat memperoleh informasi dan dapat mengembangkan pengetahuannya sendiri.peserta didik dapat memperoleh informasi dan dapat mengembangkan pengetahuannya sendiri. Hal tersebut sejalan dengan pendapat Arends (dalam Trianto, 2011), "metode pengajaran langsung (Direct Instruction) adalah salah satu pendekatan mengajar yang dirancang khusus untuk menunjang proses belajar siswa yang berkaitan dengan pengetahuan deklaratif dan pengetahuan prosedural yang terstruktur dengan baik yang dapat diajarkan dengan pola kegiatan yang bertahap, selangkah demi selangkah."

\section{KESIMPULAN}

Model pembelajarn PAIKEM tipe Direct Intruction dapat meningkatkan kemampuan berpikir kritis peserta didik.

\section{REKOMENDASI}

Bagi yang berminat untuk melakukan penelitian dengan penerapan model pembelajaran PAIKEM Tipe Direct Instructionsebaiknya dikombinasikan dengan media pembelajaran demostrasi.

\section{UCAPAN TERIMAKSIH}

Dalam penyusunan skripsi ini tidak lepas dari berbagai hambatan dan kesulitan, namun atas kehendak dan ridhonAlloh S.W.T. Serta dorongan, bantuan dan bimbingan dari berbagai pihak,akhirnya peneliti dapat menyelesaikan jurnal ini.

Selanjutnya ucapan terimaksih penulis sampaikan pula kepada: 
1. Kedua orang tua tercinta, beserta keluarga besar yang senantiasa mencurahkan perhatian, dukungan kasih saying serta do'a yang tidak hentinya dicurahkan kepada penulis demi keberhasilan dan kelancaran selama studi dan penulisan ini.

2. Ibu Tati Heryati., Dra., MM., M.Pd., selaku pembingbing I

3. Ibu Eva Nurapipah., S.Pd., selaku guru Ekonomi kelas X-IPS MA Daarussalaam

4. Bapak dan Ibu guru serta staf tata usaha MA Daarussalaam yang telah membantu dalam penelitian ini.

Semoga atas segala kebaikan, dorongan moril dan material dari bapak, Ibu serta rekan-rekan sekalian mendapatkan pahala dan ridho Alloh S.W.T. Amiin.

\section{DAFTAR PUSTAKA}

Afifah, A. N., Ilmiyati, N \& Toto. (2020). Pengaruh Model Project Based Learning (PBL) dengan Pendekatan STEM Terhadap Penguasaan Konsep dan Keterampilan Berpikir Kritis Siswa. J-KIP (Jurnal Keguruan dan IImu Pendidikan), 1 (2), 33-40.

Aryansyah, F. (2021). Pelaksanaan Question Student Have Method Dalam Meningkatkan Hasil Belajar Pada Mata Pelajaran Ekonomi di SMA. J-KIP (Jurnal Keguruan dan IImu Pendidikan), 2 (1), 9198.

Khilda, N. (2019). Pengaruh Model Pembelajaran Aktif Inovatif Kreatif Menyenangkan (PAIKEM) terhadap Kemampuan Berpikir Statistic Siswa". Jurnal Of Mathematical Science And Mathematics Education, 1 (1).

Kurniastuti, D. (2018). Peningkatan Kemampuan Berpikir Kritis Dan Prestasi Belajar Sisiwa Melalui Penggunaan Model Pembelajaran Problem Solving Dilengkapi Dengan Smart Card Pada Materi Kelautan Dan Hasil Kali Kelautan. Jurnal Pendidikan Kimia, 1 (7).

Sidik, I \& Winata, H. (2016). Meningkatkan Hasil Belajar Siswa Melalui Penerpan Model Pembelajaran Direct Instructio". Jurnal Pendidikan Manajemen Perkantoran, 1 (1).

Sugiyono. (2016). Metode Penelitian Pendidikan. Bandung: Alfabeta.

Trianto. (2011). Mendesain Modal Pembelajaran Inovatif-Progresif. Jakarta: Media Group.

Watanabe, M., McLaughlin, T. F., Weber, K. P., \& Shank, L. (2013). The Effects of Using Direct Instruction to Teach Coin Counting and Giving. International Journal of Basic and Applied Science Vol. 02 No. 01 , 150-159. 
